\title{
The impact of corporate governance practices on firm's performance: \\ An empirical evidence from Indian tourism sector
}

\author{
Mohammad Yameen \\ Department of Commerce, \\ Aligarh Muslim University, India \\ yameenmobd52@gmail.com
}

\section{Najib H. Farhan}

Department of Commerce, Aligarb Muslim University, Aligarh, UP, India

Najib720000@gmail.com

\author{
Mosab I. Tabash \\ College of Business, Al Ain University of Science and Technology, \\ $U A E$ \\ mosab.tabash@aau.ac.ae
}

\begin{abstract}
The growth of Indian companies in recent years has led to a change in the nature of the economy which attracted outsider investors from developed countries who demanded robust corporate governance practices from Indian companies which made regulators and competitors gave a great effort to restructure corporate governance. Therefore, this paper aims to investigate the effect of corporate governance practices on firms' performance, with a special reference to the Indian tourism sector. The study uses a panel dataset of 39 hotels listed on Bombay Stock Exchange (BSE) for the period from 2013/2014 to 2015/2016. The ordinary least square regression model is run for estimating the results. Findings show that board directors' size and audit committee's size negatively impact the performance of Indian hotels, while board directors' composition and diligence, the audit committee's composition and diligence, and foreign ownership positively affect the performance of Indian hotels measured by accounting proxies. Results also reveal that board directors' size, audit committee's size, and foreign ownership positively impact the Indian hotels' performance measured by marketing proxies, whereas board directors' composition; board directors' diligence; audit committee's composition; and audit committee's diligence have a negative impact on the performance of Indian hotels.
\end{abstract}

Keywords: corporate governance, firms' performance, Indian tourism sector.

JEL Classification: G21, L26, O16 


\section{INTRODUCTION}

Corporate governance can be defined as the process and structure that is used for directing and managing business' affairs in order to enhance business prosperity and corporate accountability with the ultimate objective (Mohamed, Ahmad, \& Khai, 2016). Practicing corporate governance for many Asian countries is considered as a crucial issue, especially after the financial crisis in 1997 (Mohamed et al., 2016). Corporate governance is a matter of growing importance in developing countries, many companies pass through significant transformations because of the combined forces of technological progress, sociopolitical changes, and economic trends toward globalization. In recent years, the growth of Indian companies has a lead change in the nature of the economy, external investors from developed countries demanded robust corporate governance practices from Indian companies. Therefore, regulators and competitors have given a great effort to restructure corporate governance. For organizing Indian firms, the Securities and Exchange Board of India (SEBI) ordered all firms to comply with securities regulations that were drafted by securities and exchange board of India (Chauhan, Lakshmi, \& Dey, 2016). (Bhagat \& Bolton, 2008; Duffhues \& Kabir, 2008; Yang \& Zhao, 2014) argue that corporate governance directly correlates with firms' performance. Audit committee size negatively affects large firms' performance (Detthamrong, Chancharat, \& Vithessonthi, 2017). Corporate social responsibility has a strong positive association with firms' value (Jo \& Harjoto, 2011). Corporate governance theory concerns the relationship between shareholders and the firm's management. The ownership structure and the diverse relationships between a company and its complex network of stakeholders affect firms' behavior (Rabelo \& Vasconcelos, 2002). From the point view of the individual companies, sound corporate governance practices should result in better financial opportunities, lower cost of capital, facilitation of the provision of funds in international financial markets, the better chance of overcoming crisis periods and increased liquidity (Nilsson, 2007). The main aim of different corporate governance initiatives is to promote transparency of institutional investors in order to reduce agency costs (Bassen, 2004). Government shareholdings, audit type, board size, corporate social responsibility, and leverage are some of the corporate governance variables that significantly affect the financial performance of firms in Gulf Corporation Countries (GCC) (Pillai \& Al-Malkawi, 2017). It is strongly recommended that for effective working capital policies, the formulation of such policies must be done with the recognition of corporate governance practices (Achchuthan \& Kajananthan, 2013). It is empirically found that the cash conversion cycle is negatively affected by corporate governance quality (AlRahahleh, 2016). It is reported that in manufacturing firms the presence of an independent board of directors plays an important role in shortening inventory period and cash conversion cycle (Gill, Biger, \& Obradovich, 2014). The presence of outside directors strengthens firms' performance (Mashayekhi \& Mohammad, 2008). For improving corporate governance, the focus has to be paid towards stock ownership of board members because it correlates positively with firms' performance (Sanjai Bhagat \& Bolton, 2008). A number of researchers believe that corporate governance plays a vital role in monitoring firms' operations (Fama, 1980; Fama \& Jensen, 1983). However, previous studies have shown mixed findings regarding the association between firms' performance and corporate governance practices. The growth of tourism sector in India has attracted the attention of researchers to examine some issues in the sector (Malik \& Nusrath, 2014).

The study aims to find out the impact of board directors' size, composition, and diligence; audit committee's size, composition, and diligence; and foreign ownership on the performance of Indian hotels firms. The tourism sector is one of the crucial sectors in many countries; it contributes heavily to the country's GDP. In 2015, the Indian tourism sector generated $\$ 120$ billion, almost 6.3 percent of the total GDP. It provided 37.315 million jobs for Indians. Medical tourism is one of the prosperous industries in India; most of the medical tourists are from Arab countries: 15000 foreigners came to Indian for treatment 
in 2006 (Brahmapurkar, Sahay, \& Gupta, 2015). This sector plays a vital role in developing the country's economy. It is found that despite many works that was conducted in tourism industry; corporate governance and its impact on firms' performance have not been investigated enough. The study is going to give a special focus on this issue. This study contributes to the existing literature by providing new evidence about the impact of corporate governance on tourism firms' performance measured by both accounting and marketing based measures: studies that investigated the impact of corporate governance on tourism firms' performance all around the world are few and most of them confined only to accounting based measures; moreover, Indian tourism sector is still untouched. Therefore, the researcher decided to undertake this research to examine corporate governance practice in the sector.

The present study is divided into 6 sections: Section 2 reviews the previous research work, section3 provides an overview about tourism sector and corporate governance practices in India, section4 demonstrates the applied research methodology in the study, section5 discusses the empirical results, and section 6 summarizes, concludes the whole paper, and illustrates the limitations and recommendations for future studies.

\section{LITERATURE REVIEW}

An enormous number of research papers have evaluated corporate governance impact on firms' performance (Durnev \& Kim, 2005; Klapper \& Love, 2004). Pillai \& Al-Malkawi (2017) aimed to examine the influence of corporate governance's internal mechanisms on the financial performance of some companies in GCC countries for the period from 2005 to 2012. Results indicated that the financial performance is negatively affected by government shareholdings, board size, audit type, leverage, and corporate social responsibility. Shleifer \& Vishny (1997) believe that controlling ownership could be the only technique to mitigate the agency problems that come with the partition of ownership and control. Alabdullah, Yahya, Nor, \& Majeed (2016) attempted to investigate the impact of corporate governance mechanisms in Jordan on firms' performance. 109 non-financing companies were selected. The study is based on cross-sectional data for the year 2011, it was found that board directors' size has a positive impact on the level of financial leverage which in turn enhances firms' performance. Gill et al. (2014) evaluated the impact of independent board directors on cash conversion cycle; a sample of 189 American manufacturing firms was taken. It was found that board directors' independence plays an important role in reducing number of days' inventory holding period and cash conversion cycle. Chauhan, Lakshmi, \& Dey (2016) examined corporate governance effect on the financial performance of 84 Indian firms for ten years from 2003 to 2013. The study found that there is a positive association between corporate governance variables and firms' performance which means that corporate governance is one of the factors that enhance firms' performance. (Chen, Firth, Gao, \& Rui, 2006; Claessens \& Fan, 2002) provided humble evidence which proves that selfdealings harm firm performance. Board ownership and board composition have an impact on business failure (Priego \& Merino, 2016). Detthamrong, Chancharat, \& Vithessonthi, (2017) tried to assess the association between corporate governance and firms' performance of 493 firms in Thailand. They argued that there is no association between firms' performance and corporate governance. Aldamen, Duncan, Kelly, McNamara, \& Nagel (2012) examined the impact of audit committee characteristics on performance of 300 listed firms during the financial crisis. It was expected that audit committee characteristic positively associates with firms' performance. Surprisingly, it was found that audit committee characteristics negatively correlate with firms' performance during the financial crisis. Arora \& Sharma (2015) examined the impact of Indian firms' performance on board directors' characteristics. It was found that firms' performance negatively impacts board characteristics. Arora \& Sharma (2016) conducted a study to find out the impact of corporate governance on the financial performance of Indian manufacturing companies from more than 20 industries. It was found that larger boards are associated with good intellectual knowledge which leads to better decision making and improving the firms' performance. Gull, Saeed, \& Abid (2013) sought to 
examine the impact of corporate governance on the performance of firms operating in Pakistan, analyzing data for the period from 2007 till 2011. It was found that there is a positive relationship between board directors' size and firms' performance. Jo \& Harjoto (2011) argue that board independence, board leadership, block holder's ownership, and institutional ownership weakly impact firms' value, while corporate social responsibility strongly impacts firms' value. Many variables used in previous literature for measuring corporate governance; this study took the most relevant variables as proxies for corporate governance. All chosen variables are discussed below for developing a good understanding:

\subsection{Board of directors' size and firms' performance}

Many researchers argue that firms' performance differs according to the size of board of directors. When the number of directors on the board is large, firms would get more access to various resources in comparison to the case when board size is small. The larger board of directors, the more experienced and knowledgeable people will be available which will lead to more careful learning, decision making process and ultimately better firm performance. Larger board of directors is harmful to firms' performance (Switzer \& Tang, 2009). Arora (2012) examined the impact of board directors' size on the performance of 150 pharmaceutical companies for the period from 2001 to 2010, the study found that board directors' size has a positive impact on firms' performance. Anderson, Mansi, \& Reeb (2004) believe that board directors' size plays a vital role in improving firms' performance as it enables the companies to control and oversee managers. For instance, Yermack (1996) found that there is a negative association between firms' performance and number of board directors. The study was based on a sample of 452 companies in U.S industrial corporations over the period from 1984 to 1991. However, Jackling \& Johl (2009) found that number board of directors has a positive impact on Indian firms' performance. Similarly, there is a positive correlation between board size and firms' performance (Johl, Kaur, \& Cooper, 2015).in the same line, Alabdullah et al. (2016) argue that board directors' size positively impacts firms' performance by reducing the financial leverage level. Citation \& Chatterjee (2011) argue that board directors' size negatively impacts firms' performance measured by market-based measures. It is believed that board directors' size is a vital influential over firms' performance. Thus, this study expects board directors' size to have a positive impact on firms' performance.

\subsection{Board independence and firms' performance}

Board of directors include a number of executives who might be non-independent or independent directors. The board provides essential work as it monitors the management team of the firm. A large number of independent directors are preferable for investors. It is also called outside director (Muniandy \& Hillier, 2015). Many studies were conducted to investigate the association between board independence and firms' performance; Switzer \& Tang (2009) investigated the impact of degree of board independence on the performance of 245 Small-Cap firms U.S for the period from 2000 to 2004; it was found that degree of board independence positively correlates with firms' performance. Citation \& Chatterjee (2011) aimed to explore the relationship between board directors' independence and Indian firms, the sample covered public, private, undertaking, standalone firms, and subsidiaries foreign firms. It was found that board independence insignificantly impacts all types of companies. Agrawal \& Knoeber (1996) found that there is a positive association between firms' value and board directors. Jackling \& Johl (2009) believe that firms' performance is positively impacted by board independence. There is a low positive association between board composition and financial performance (Spring \& Rhoades, 2017). Johl et al., (2015) advocate that board independence have no impact on firms' performance. Arora (2012) believes that board directors' composition negatively affects firms' performance. On the other hand, Alabdullah et al. (2016) advocate 
that board independence has no impact on firms' performance. It is argued in the literature that independent board directors positive effects firms performance by reducing the agency cost. Therefore, it is predicted that board independence has a positive impact on the firms' performance in tourism sector.

\subsection{Board of directors diligence and firms' performance}

Board of directors' diligence is measured by the number of board meetings, the frequency of meetings is the time devoted for monitoring management. It was found that when board members meet more frequently, the performance improves as a result (Rizzotti \& Greco, 2013; Vafeas, 1999). Board meetings are very essential for directors as they used the attendance as a channel which enables them to monitor properly (Johl et al., 2015). It is needed for subcommittees to hold its meeting before or after the meeting, due to unavailability of time for the board members (Raghunandan \& Rama, 2007). Johl et al., (2015) believe that board meetings have a diverse impact on firms' performance. It was found that the companies that had a bad performance during the financial crises had poor board attendance at meetings while the companies that performed well have a good board attendance meeting (Francis, Hasan, \& Wu, 2012). Board meetings negatively affect firms' performance (Arora, 2012). On the contrary, Arora \& Sharma (2016) found that board of directors positively impacts firms' performance. There are conflicting results in the existing literature regarding the impact of board of directors' diligence on firms' performance. Subsequently, the study predicts that board of directors' diligence in tourism sector has a negative impact on the financial performance.

\subsection{Audit committee size and firms' performance}

Audit committee is one of the important factors that play a vital role in boosting firms' performance, it provides a sufficient protection against fraud and makes sure that these protections are in accordance with the best practices. Audit committee members must be qualified holders and have the experience in the field of auditing (Aldamen, Duncan, Kelly, McNamara, \& Nagel, 2012). Small audit committee size that consists of well-experienced members and financial expertise associates positively with firms' performance (Aldamen et al., 2012). Detthamrong et al. (2017) investigated the impact of corporate governance on firms' performance of 493 non-financial companies in Thailand. It was found that audit committee size has an impact on firms' performance. Beasley (1996) argued that audit committee role makes sure of meeting the quality of financial reporting. However, audit committee presence does not affect the financial statement fraud. Aldamen et al. (2012) advocated that there is a negative association between audit committee and firms' performance. Based on the discussion above the study anticipates a negative impact of audit committee size on firms' performance in tourism sector.

\subsection{Audit committee composition and firms' performance}

As board directors consist of independent and dependent directors, audit committee comprises of dependent and independent members as well. If there are more independent members in the audit committee, the audit committee effectively protects firms' financial reporting. Good corporate governance practice like audit committee enhances the monitoring of management (Aldamen et al., 2012). A high proportion of independent audit committee enhances' firms' value (Chan \& Li, 2008). Anderson, Mansi, \& Reeb (2004) found that full independent audit committee significantly correlates with financing cost. Audit committee is a crucial element that impacts financial reports reliability. Anderson et al. (2004) found that there is a correlation between audit committee composition and cost of debt. Bédard, Chtourou, \& Courteau (2004) affirmed that when all audit committee members are independent that leads to reducing earning 
management. Based on previous literature, the study expects audit committee composition to have a positive impact on firms' financial performance.

\subsection{Audit committee diligence and firms' performance}

Audit committee diligence refers to the number of committee meetings that are held yearly. Some studies argue that frequent meetings of audit committee may reduce the number of financial reporting problems (Yatim, Kent, \& Clarkson, 2006). Audit committee diligence shows audit members' willingness to work together and maintain a high level of activity as they have to deal with the external and internal auditors, management and other constituents (Rizzotti \& Greco, 2013). If audit committee meetings are held frequently, the committee would be aware and then they will alert the auditor on the auditing issues that require attention and care (Raghunandan, K.R., Rama \& Scarbrough, 1998). When there is an increase in the number of independent directors, audit committee meetings increase (Thiruvadi, 2012). Based on the reviewed literature about corporate governance practice in Indian tourism sector, the study expects audit committee diligence to positively impact the performance of Indian hotels.

\subsection{Foreign ownership and firms' performance}

Ownership separation and control offer a good opportunity for managers to make decisions that benefit or harm the performance of a firm. Concentration control of ownership would lower the problems between managers and owners (Maury, 2006). BSE code of corporate governance states that board ought to set a committee that helps out in fulfilling board responsibilities. Bayrakdaroglu, Ersoy, \& Citak (2012) investigated the association between ownership structure and firms' performance. The study adopted a balanced panel data of 59 listed companies. It was found that foreign ownership positively affects firms' performance. Alabdullah et al. (2016) argue that companies' ownership structure is an important determinant that reduces the agency problems between the shareholders and management. Nguyen (2011) argues that the increase in ownership concentration leads to increasing the idiosyncratic risk. Wiwattanakantang (2001) found some evidence that prove the positive association between ownership concentration and firms' performance. Agency theory suggests that ownership concentration results in an effective monitoring. It also alleviates the conflict among the managers and owners. Subsequently, the study expects a positive impact on the performance of Indian hotels.

Based on the above discussion, the study found that majority of previous studies in the literature on corporate governance and firms' performance used accounting-based measures as a proxy for measuring firms' performance. Therefore, the study contributes to the existing literature by providing new evidence about the impact of corporate governance on tourism firms' performance measured by both accounting and marketing based measures. Furthermore, Indian tourism sector is still untouched which encouraged the researcher to conduct his study.

\section{TOURISM SECTOR AND CORPORATE GOVERNANCE PRACTICES IN INDIA}

Tourism sector is one of the important sectors in India, it plays a vital role in economic development (Singh Jaswal, 2014). Indian tourism sector is anticipated to obtain the fastest growth rate among other sectors in the country (Planning Commission Government of India, 2007). Statistical records show that in terms of international visitors/ tourists; there is a growth of 13.9 percent a year while the number of domestic tourists grows rapidly and getting doubled (Jones Lang LaSalle Hotels, 2008). 


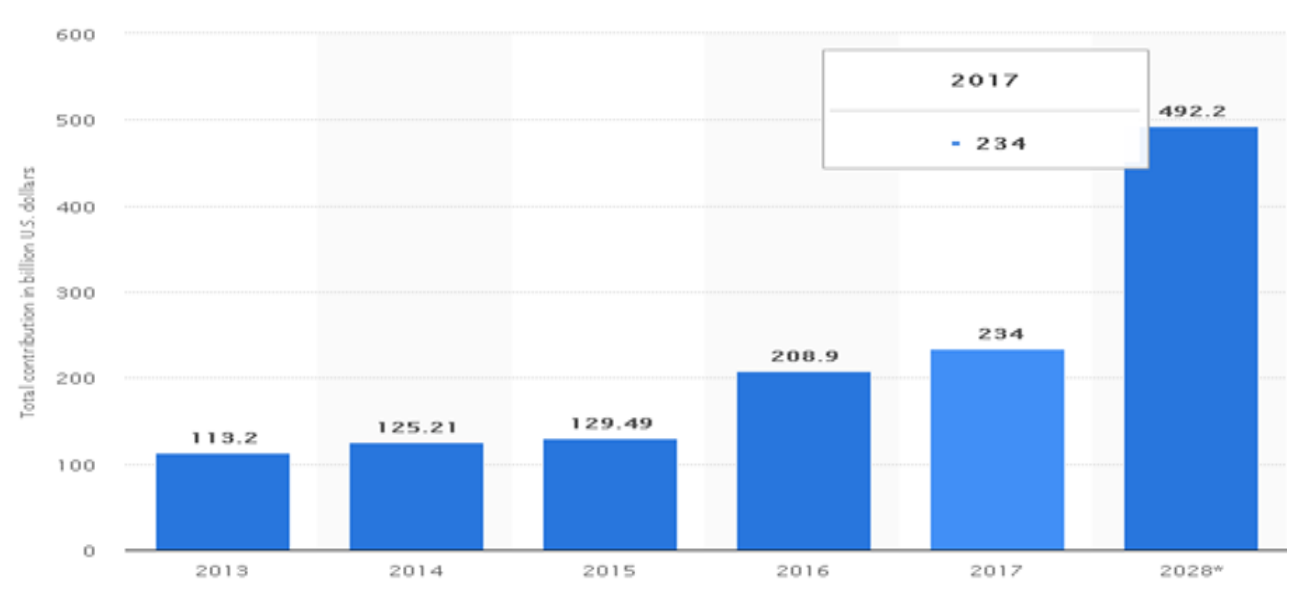

Figure 1. Total contribution of travel and tourism sector to GDP in India from 2013 to 2028 (in billion U.S. dollars).

Source: Statistic Portal ${ }^{1}$

Figure 1 demonstrates the total contribution of travel and tourism sector to the Indian GDP for the period from 2013 to 2017. In addition to that, it illustrates the anticipated contribution of the sector to the country's GDP for the period from 2017 to 2028 . The figure shows that there is a slight increase from the year 2013 till the year 2015 and then it increased significantly from $\$ 129.49$ billion dollars in 2015 to $\$ 234$ billion dollars in 2017. Among all Asian countries, Thailand has the highest record of international tourists; it is the favorite destination of approximately $27 \%$ of tourists who come to Asia. In 2015, Thai tourism sector contributed about $20.8 \%$ percent to the total GDP of the country (Brahmapurkar et al., 2015). Figure 2 illustrates the amount of fund received from international tourist arrived at some Asian and Pacific countries in 2016; Thailand, China, and Hong Kong (China) are coming first by receiving $\$ 49.87, \$ 44.43$, and $\$ 32.42$ billion dollars respectively. India is coming seventh after Australia, Japan and Macao (China) by receiving $\$ 22.43$ billion dollars; New Zealand and Vietnam are at the bottom of the list by receiving 9.64 and 8.25 respectively.

In business environment, globalization did not only significantly affect business risk of Indian companies, but also forced Indian companies especially that are working in tourism sector to adopt the international norms and good corporate governance practices. The implementation of corporate governance in Indian and other countries did not come from the vacuum, it emerged as a crucial factor after the major corporate scams and failures that were recorded at Worldcom, Enron, and Adelphia. These frauds and scams underlined the need for good practice for corporate governance regulations (Rajab \& HandleySchachler, 2009). The world biggest financial crisis/credit crunch in 2007/2008 followed by 2009 Satyam computer scam in India Stir up the debate of weak corporate governance regulations and lack of transparency by the corporates.

\footnotetext{
${ }^{1}$ https://www.statista.com/statistics/313724/total-contribution-of-travel-and-tourism-to-gdp-in-india-by-segment/
} 


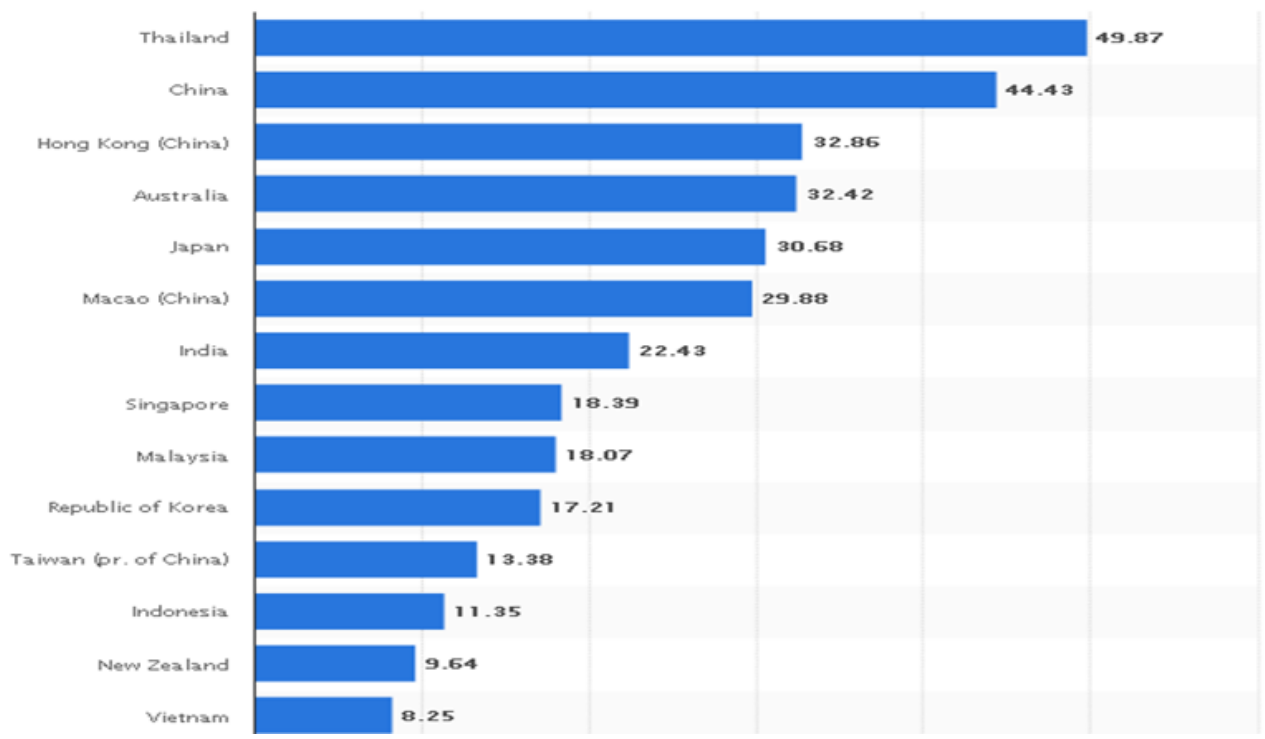

Figure 1. Countries in Asia/Pacific region with the largest international tourism receipts in 2016 (in billion U.S. dollars) ${ }^{2}$

The current rules of corporate governance in Clause 49 were stabilized in 1998 by the corporate governance voluntary code that initiated by the Confederation of Indian Industry (1998). It seems that Indian corporates wished to follow higher corporate governance and disclosure standards (Khanna \& Black, 2007). Industries in India were influenced by SEBI to adopt corporate governance rules as part of the requirements for any company to be listed; it is because the voluntary code was seen as insufficient to grab the attention of foreign investors. In 2003 the new version of Clause 49 which was set in 2001 was put mandatory for all companies with a paid-up capital of over 30 million to follow. Clause 49 was reviewed based on the suggestion of Narayanamurthy committee in August 2003, but due to the opposition of corporate sector, Clause 49 was amended and a new version was issued in 2004 (National Foundation for Corporate Governance, 2004). After the changes of Clause 49 made applicable to all listed firms from January 2006 under provision 21 of the Securities Contract Act of 1956 (SEBI, 2008), listed companies are statutorily bound to comply with the requirements of Clause 49. The growth of tourism sector in India has attracted the attention of researchers to undertake investigations (Malik \& Nusrath, 2014). It is found that despite the large number of research that was conducted in tourism industry, corporate governance and its impact on firms' performance has not been investigated enough. This study is going to give a special focus on this issue.

\section{METHODOLOGY}

\subsection{Sample selection and sources of data}

The study aims to find out the impact of corporate governance on the financial performance of Indian hotels. The main focus is only on the hotels that are listed on Bombay Stock Exchange; there are only 53 hotels listed on Bombay Stock Exchange. The study adopted a panel data approach of 39 hotels for the

\footnotetext{
2 https://www.statista.com/statistics/261749/tourism-receipts-of-selected-asian-and-pacific-countries/
} 
period from 2013/2014 to 2015/2016. The study excluded the hotels that do not have data for the study period. After elimination of 14 hotels, the final sample comprises of 39 hotels. Two sources are used for collecting the data, companies' annual reports and ProwessIQ database 3 . Corporate governance data are taken directly from the companies' annual reports, in which the study reviews the annual reports for three years for each company. The financial data are extracted form ProwessIQ database (Indian's leading financial information source).

\subsection{Research design}

The market-based measure seems to be more suitable than accounting-based measures, but they are also affected by a number of uncontrollable factors (Gani \& Jermias, 2006). Hutchinson \& Gul (2004) believe that for reflecting the results of management actions, account-based measures are preferable to market-based measures for evaluating the impact of corporate governance on firms' performance. Prior studies (e.g., (Akbar, Poletti-hughes, El-faitouri, \& Zulfiqar, 2016; Detthamrong et al., 2017; Fiador, 2016; Mashayekhi \& Mohammad, 2008; Mohamed et al., 2016; Pillai \& Al-Malkawi, 2017) studied the relationship between corporate governance and firms' performance using some proxies for measuring the financial performance such as: return on assets, return on equity, return on investment, earning per share, and Tobin's Q. This study is adopting the same approach for measuring financial performance, taking some accounting and marketing based measures. The study took seven variables as proxies for measuring corporate governance which are: board size, board composition, board diligence, audit committee size, audit committee composition, audit committee diligence, and foreign ownership.

Some studies (e.g., Chauhan et al., 2016; Mashayekhi \& Mohammad, 2008; Priego \& Merino, 2016) suggested that firm size may affect firms performance. Therefore, net sales, firm age (number of years since its establishment), and firm size (total assets) are used as control variables; the natural a logarithm of total assets is used as an indicator of firm size. The study is adopting multiple correlations and regression analysis to find out the effect of corporate governance practices on the performance of Indian hotels. This adoption was motivated by some studies e.g. (Chauhan et al., 2016; Mashayekhi \& Mohammad, 2008; Priego \& Merino, 2016).

\subsection{Models specification}

To investigate the impact of corporate governance variables on the performance of Indian hotels, seven regression models are designed as follows:

$$
\begin{aligned}
& \mathrm{FP}_{\mathrm{it}=} \alpha+\beta_{1} \mathrm{BDS}_{\mathrm{it}}++\beta_{2} \mathrm{AGE}_{\mathrm{it}}+\beta_{3} \mathrm{NS}_{\mathrm{it}}+\beta_{4} \mathrm{LOGTA}_{\mathrm{it}}+\varepsilon_{\mathrm{it}} \\
& \mathrm{FP}_{\mathrm{it}=} \alpha+\beta_{2} \mathrm{BDC}_{\mathrm{it}}+\beta_{2} \mathrm{AGE}_{\mathrm{it}}+\beta_{3} \mathrm{NS}_{\mathrm{it}}+\beta_{14} \mathrm{LOGTA}_{\mathrm{it}}+\varepsilon_{\mathrm{it}} \\
& \mathrm{FP}_{\mathrm{it}}=\alpha+\beta_{1} \mathrm{BDD}_{\mathrm{it}}+\beta_{2} \mathrm{AGE}_{\mathrm{it}}+\beta_{3} \mathrm{NS}_{\mathrm{it}}+\beta_{140} \text { LOGTA }_{\text {it }}+\varepsilon_{\mathrm{it}} \\
& \mathrm{FP}_{\mathrm{it}=} \alpha+\beta_{1} \mathrm{ACS}_{\mathrm{it}}+\beta_{2} \mathrm{AGE}_{\mathrm{it}}+\beta_{3} \mathrm{NS}_{\mathrm{it}}+\beta_{4} \mathrm{LOGTA}_{\mathrm{it}}+\varepsilon_{\mathrm{it}} \\
& \mathrm{FP}_{\mathrm{it}=} \alpha+\beta_{1} \mathrm{ACC}+\beta_{2} \mathrm{AGE}_{\mathrm{it}}+\beta_{3} \mathrm{NS}_{\mathrm{it}}+\beta_{4} \mathrm{LOGTA}_{\mathrm{it}}+\varepsilon_{\mathrm{it}} \\
& \mathrm{FP}_{\mathrm{it}=} \alpha+\beta_{1} \mathrm{ACD}_{\mathrm{it}}+\beta_{2} \mathrm{AGE}_{\mathrm{it}}+\beta_{3} \mathrm{NS}_{\mathrm{it}}+\beta_{4} \mathrm{LOGTA}_{\mathrm{it}}+\varepsilon_{\mathrm{it}} \\
& \mathrm{FP}_{\mathrm{it}=} \alpha+\beta_{1} \mathrm{FO}_{\mathrm{it}}+\beta_{2} \mathrm{AGE}_{\mathrm{it}}+\beta_{3} \mathrm{NS}_{\mathrm{it}}+\beta_{4} \mathrm{LOGTA}_{\mathrm{it}}+\varepsilon_{\mathrm{it}}
\end{aligned}
$$

Where

\footnotetext{
3 PROWESS database is the Indian's leading financial information source, it is maintained by CMIE and is broadly similar to Compustat database of US firms. It is increasingly being employed in the literature for firm-level analysis of Indian industry and contains financial information on around 27,000 companies, either listed on stock exchanges or the major unlisted companies.
} 
$\alpha$ is the intercept.

$\varepsilon$ is the error term of the model.

$i$ and $t$ correspond to firm and year.

FP is the financial performance measured by return on assets, return on capital employed, and Tobin Q.

BDS refers to number of board directors.

$\mathrm{BDC}$ is the number of independent directors to the total number of board director.

BDD refers to the attended meetings out of the total meetings.

ACS is number of audit committee directors.

ACC is number of independent audit members to the total number of audit committee.

ACD is attended meetings by audit committee out of the total meetings.

FO refers to the number of shares which are in the hand of foreign investors.

Age is the age of the company.

$\mathrm{NS}$ is net sales.

LOGTA is the log of total assets

\subsection{Variables description}

Table 1

\section{Variables Description}

\begin{tabular}{|c|c|c|c|c|}
\hline Variable & Symbol & Definition & ES & Existing Studies \\
\hline $\begin{array}{l}\text { Return on } \\
\text { Assets }\end{array}$ & $\mathrm{ROA}$ & $\begin{array}{l}\text { Net income divided by total assets } \\
\text { at the end of the year. It is one of } \\
\text { the accounting measures of firms' } \\
\text { performance. The data of this } \\
\text { variable was extracted from } \\
\text { ProwessIQ database. }\end{array}$ & & $\begin{array}{l}\text { (Chauhan et al., 2016; Detthamrong et al., } \\
\text { 2017; Mashayekhi \& Mohammad, 2008; } \\
\text { Pillai \& Al-Malkawi, 2017, Yahya, et al, } \\
\text { 2017; Tabash, et al, 2017) }\end{array}$ \\
\hline $\begin{array}{l}\text { Return on } \\
\text { Capital } \\
\text { Employed }\end{array}$ & ROCE & $\begin{array}{l}\text { Profit before tax on total issued } \\
\text { capital, it is the second accounting } \\
\text { based measure used by this study } \\
\text { and its data also extracted from } \\
\text { ProwessIQ database. }\end{array}$ & & $\begin{array}{l}\text { (Filatotchev, Isachenkova, \& Mickiewicz, } \\
\text { 2007; Uadiale, 2010) }\end{array}$ \\
\hline Tobin Q & TQ & $\begin{array}{l}\text { Market capitalization over total } \\
\text { asset of the company. It is a } \\
\text { marketing-based measure and it was } \\
\text { collected from ProwessIQ database. }\end{array}$ & & $\begin{array}{l}\text { (H. Ibrahim \& AbdulSamad, 2011; Kang } \\
\text { \& Kim, 2011; Karaca \& Ekşi, 2012) }\end{array}$ \\
\hline $\begin{array}{l}\text { Board } \\
\text { Directors } \\
\text { Size }\end{array}$ & BDS & $\begin{array}{l}\text { Total number of board members } \\
\text { setting in the board. Its data was } \\
\text { collected from the companies' } \\
\text { annual reports. }\end{array}$ & + & $\begin{array}{l}\text { (AGYEI \& OWUSU, 2014; Al-bassam, } \\
\text { Ntim, Opong, \& Downs, 2015; Chitiavi, } \\
\text { Musiega, Alala, Douglas, \& Christopher, } \\
\text { 2013; Ghabayen, 2012; K. Ibrahim \& } \\
\text { Jaafar, 2013; Jackling \& Johl, 2009; Johl, } \\
\text { Kaur, \& Cooper, 2015; Mousa \& Desoky, } \\
\text { 2012; Pillai \& Al-Malkawi, 2017; } \\
\text { Yermack, 1996) }\end{array}$ \\
\hline $\begin{array}{l}\text { Board } \\
\text { Directors } \\
\text { Composition }\end{array}$ & $\mathrm{BDC}$ & $\begin{array}{l}\text { No. non-executive independent } \\
\text { members divided by the total No. of } \\
\text { members setting in the board. Its } \\
\text { data was collected from companies' } \\
\text { annual reports. }\end{array}$ & + & $\begin{array}{l}\text { (Agrawal \& Knoeber, 1996; Sanjai Bhagat } \\
\text { \& Blak, 2016; Johl et al., 2015; Mahadeo, } \\
\text { Soobaroyen, \& Hanuman, 2012; } \\
\text { Mashayekhi \& Mohammad, 2008; Nahar } \\
\text { Abdullah, 2004; Rhoades, Rechner, \& } \\
\text { Sundaram, 2017) }\end{array}$ \\
\hline $\begin{array}{l}\text { Board } \\
\text { Directors } \\
\text { Diligence }\end{array}$ & BDD & $\begin{array}{l}\text { Total number of meetings attended } \\
\text { by all board members scaled by total } \\
\text { No. of meetings held during the }\end{array}$ & - & $\begin{array}{l}\text { (Francis, Hasan, \& Wu, 2012; Johl et al., } \\
\text { 2015) }\end{array}$ \\
\hline
\end{tabular}




\begin{tabular}{|c|c|c|c|c|}
\hline & & $\begin{array}{l}\text { year. Its data was collected from } \\
\text { companies' annual reports. }\end{array}$ & & \\
\hline $\begin{array}{l}\text { Audit } \\
\text { Committee } \\
\text { Size }\end{array}$ & ACS & $\begin{array}{l}\text { An absolute number of audit } \\
\text { committee members in a firm. Its } \\
\text { data was collected from companies' } \\
\text { annual reports. }\end{array}$ & + & $\begin{array}{l}\text { (Detthamrong et al., 2017; Francis et al., } \\
\text { 2012) }\end{array}$ \\
\hline $\begin{array}{l}\text { Audit } \\
\text { Committee } \\
\text { Composition }\end{array}$ & ACC & $\begin{array}{l}\text { No. of Independent audit } \\
\text { committee members divided by } \\
\text { total No. of audit committee } \\
\text { members. Its data was collected } \\
\text { from the companies' annual reports. }\end{array}$ & - & $\begin{array}{l}\text { (Al-Janadi, Rahman, \& Alazzani, 2016; } \\
\text { Aljaaidi, 2013; Bédard et al., 2004) }\end{array}$ \\
\hline $\begin{array}{l}\text { Audit } \\
\text { Committee } \\
\text { Diligence }\end{array}$ & $\mathrm{ACD}$ & $\begin{array}{l}\text { Total No. of meetings attended by } \\
\text { all audit committee members } \\
\text { divided by the total No. of meetings } \\
\text { held during the year. Its data was } \\
\text { collected from companies' annual } \\
\text { reports. }\end{array}$ & + & $\begin{array}{l}\text { (Aljaaidi, 2013; Krishnan and } \\
\text { Visvanathan, 2009) }\end{array}$ \\
\hline $\begin{array}{l}\text { Foreign } \\
\text { Ownership }\end{array}$ & $\mathrm{FO}$ & $\begin{array}{l}\text { Percentage of shares owned by } \\
\text { foreigners to the total share capital. } \\
\text { It is calculated by dividing the } \\
\text { amount of foreign capital /total } \\
\text { equity. Its data was collected from } \\
\text { companies' annual reports. }\end{array}$ & + & $\begin{array}{l}\text { (Arouri \& Hossain, 2014; Fallatah \& } \\
\text { Dickins, 2012) }\end{array}$ \\
\hline Net Sales & NS & $\begin{array}{l}\text { Total sales minus return sales. Its } \\
\text { data was collected from ProwessIQ } \\
\text { database. }\end{array}$ & + & $\begin{array}{l}\text { (Abuzayed, 2012; Afrifa \& Padachi, 2016; } \\
\text { Banos-Caballero et al., 2012; Deloof, } \\
\text { 2003) }\end{array}$ \\
\hline Firm Size & LOGTA & $\begin{array}{l}\text { The logarithm of total assets. Its } \\
\text { data was collected from the } \\
\text { ProwessQ data base. }\end{array}$ & - & $\begin{array}{l}\text { (Elangkumaran \& Karthika, 2013; Mehta, } \\
\text { 2017; Rizzotti \& Greco, 2013) }\end{array}$ \\
\hline Firm Age & Age & $\begin{array}{l}\text { A number of years in which the firm } \\
\text { has been operating. Its data was } \\
\text { collected from ProwessIQ database. }\end{array}$ & + & (Afrifa, 2016; Afrifa \& Padachi, 2016) \\
\hline
\end{tabular}

\section{EMPIRICAL RESULTS AND DISCUSSION}

\subsection{Descriptive statistics}

Table 2 presents the descriptive statistics for every year individually and the overall period of the study. The average values of financial performance measures ROA, ROE and Tobin Q are 2.03, 2.97, and 0.794 respectively. The minimum number of board of directors in hotels' industry is 3 , while the maximum is 16 . The minimum values of board size composition and board diligence are 0.5 and 0.6 respectively. Regarding board of directors, cross-sectional descriptive statistics show a slight improvement in corporate governance practices over the years from 2013/2014 till 2015/2016. The industry has an audit committee size ranging from 2 to 6 . The mean values of audit committee composition and audit committee diligence are 0.72 and 0.83 respectively. Table 2 reveals that there is a fluctuation in corporate governance practices regarding audit committee over the study period. The average foreign ownership in hotel industry is $12.7 \%$. Cross-sectional descriptive statistics reveal a persistent decline in the portion of foreign ownership over the study period. The average of annual sales in hotel industry is 1551.58 Crore (1 Crore equals U.S \$145,950) with a standard deviation of 1901.89 which is the highest S.D in the model. The youngest firm in the sample is aged 7 years and the oldest firm is aged 67 years. 
Descriptive Statistics

\begin{tabular}{|c|c|c|c|c|c|c|c|c|c|}
\hline \multirow[b]{2}{*}{$\begin{array}{l}\text { Variable } \\
\text { s Type }\end{array}$} & \multirow{2}{*}{$\begin{array}{l}\text { Variable } \\
\text { s }\end{array}$} & \multicolumn{2}{|c|}{$2013 / 2014$} & \multicolumn{2}{|c|}{$2014 / 2015$} & \multicolumn{2}{|c|}{$2015 / 2016$} & \multicolumn{2}{|c|}{ Overall Sample } \\
\hline & & Mean & $\begin{array}{c}\text { Std. } \\
\text { Deviatio } \\
\mathrm{n}\end{array}$ & Mean & $\begin{array}{c}\text { Std. } \\
\text { Deviatio } \\
\mathrm{n}\end{array}$ & Mean & $\begin{array}{c}\text { Std. } \\
\text { Deviatio } \\
\mathrm{n}\end{array}$ & Mean & $\begin{array}{c}\text { Std. } \\
\text { Deviatio } \\
\mathrm{n}\end{array}$ \\
\hline \multirow{3}{*}{ 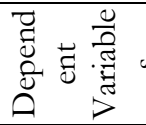 } & ROA & 2.07 & 4.81 & 1.73 & 4.76 & 2.31 & 4.32 & 2.03 & 4.60 \\
\hline & ROCE & 3.08 & 6.39 & 2.57 & 5.94 & 3.26 & 5.51 & 2.97 & 5.91 \\
\hline & Tobin Q & 0.76 & 0.66 & 0.87 & 0.80 & 0.75 & 0.66 & 0.79 & 0.71 \\
\hline \multirow{7}{*}{ 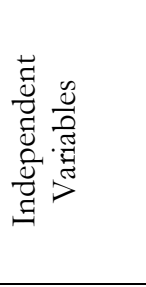 } & BDS & 7.69 & 2.65 & 7.95 & 2.61 & 7.85 & 2.54 & 7.83 & 2.58 \\
\hline & $\mathrm{BDC}$ & 0.53 & 0.10 & 0.51 & 0.09 & 0.51 & 0.10 & 0.52 & 0.10 \\
\hline & BDD & 0.78 & 0.13 & 0.78 & 0.12 & 0.81 & 0.12 & 0.79 & 0.12 \\
\hline & ACS & 3.87 & 0.89 & 4.10 & 1.05 & 3.92 & 0.98 & 3.97 & 0.97 \\
\hline & $\mathrm{ACC}$ & 0.71 & 0.19 & 0.72 & 0.20 & 0.75 & 0.18 & 0.73 & 0.19 \\
\hline & ACD & 0.86 & 0.14 & 0.81 & 0.17 & 0.85 & 0.14 & 0.84 & 0.15 \\
\hline & $\mathrm{FO}$ & 14.32 & 23.30 & 12.36 & 22.86 & 11.69 & 21.27 & 12.79 & 22.33 \\
\hline \multirow{3}{*}{ 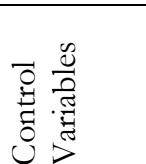 } & Age & 28.28 & 12.54 & 29.26 & 12.53 & 30.26 & 12.53 & 29.27 & 12.45 \\
\hline & NS & $\begin{array}{r}1612.8 \\
7\end{array}$ & 2019.71 & $\begin{array}{r}1503.1 \\
9\end{array}$ & 1848.19 & $\begin{array}{r}1538.7 \\
0\end{array}$ & 1881.63 & $\begin{array}{c}1551.5 \\
9\end{array}$ & 1901.90 \\
\hline & LOGTA & 3.30 & 0.74 & 3.30 & 0.76 & 3.36 & 0.66 & 3.32 & 0.71 \\
\hline
\end{tabular}

Table 2 shows that good records for ROA and ROCE of Indian hotels were achieved in the year 2015/2016, whereas TQ was achieved in the year 2014/2015. In terms of independent variables, BDS and ACS have more members in the year 2014/2015; the mean of board directors' size in tourism sector is 7.95 members and the mean of audit committee size is 4.10. On the other hand, BDD and ACC have the highest mean in the year 2015/2016, the mean values of BDC, ACD, and FO in 2013/2014 were: $0.53,0.86$ and14.32 respectively.

\subsection{Correlation matrix and multicollinearity test}

Correlation matrix reveals the trend of association between variables, and tells us how significant the association between variables of the study is. It also gives an indication regarding the absence and presence of multicollinearity. If an independent variable in a model has tolerance coefficients value below 0.10 , it means that the model is suffering from multicollinearity (Field, 2009). Table 3 represents the multicollinearity test and coefficient correlation matrix for all variables. It is shown in Table 3 that BDC and ACS have a negative association with all measures of financial performance in tourism sector, this result consistent with (Aldamen et al. 2012; Arora, 2012) who argue that there is a negative association between ACS and firms' performance. This result also contradicts with (Jackling \& Johl, 2009; Rhoades et al., 2017) who believe that firms' performance is positively impacted by the number of independent board directors. 
Correlation Matrix and Multicollinearity Test

\begin{tabular}{|c|c|c|c|c|c|c|c|c|c|c|c|c|c|}
\hline & $\mathrm{ROA}$ & ROCE & $\begin{array}{c}\text { Tobin } \\
\mathrm{Q} \\
\end{array}$ & BDS & BDC & BDD & ACS & $\overline{A C C}$ & ACD & FO & Age & NS & LOGTA \\
\hline ROA & 1 & & & & & & & & & & & & \\
\hline ROCE & $.962 * *$ & 1 & & & & & & & & & & & \\
\hline Tobin Q & $.573 * *$ & $.585^{*}$ & 1 & & & & & & & & & & \\
\hline BDS & -.077 & -.057 & .048 & 1 & & & & & & & & & \\
\hline BDC & -.010 & -.039 & -.164 & -.154 & 1 & & & & & & & & \\
\hline BDD & .109 & .107 & -.048 & -.131 & .096 & 1 & & & & & & & \\
\hline ACS & -.108 & -.070 & .085 & $.510 * *$ & $-.223^{*}$ & -.129 & 1 & & & & & & \\
\hline ACC & .114 & .095 & -.053 & -.005 & $.280 * *$ & -.042 & $-.341 * *$ & 1 & & & & & \\
\hline ACD & .102 & .111 & -.087 & $-.213^{*}$ & .176 & $.308^{* *}$ & $-.478^{* *}$ & $.265^{* *}$ & 1 & & & & \\
\hline FO & -.033 & -.048 & -.099 & .078 & .021 & -.077 & -.013 & -.070 & -.115 & 1 & & & \\
\hline Age & .118 & .096 & $.231 *$ & -.018 & .001 & -.027 & .128 & -.098 & -.100 & $-.249 * *$ & 1 & & \\
\hline NS & -.104 & .061 & .111 & $.518^{* *}$ & -.064 & -.054 & $.274 * *$ & -.116 & -.065 & -.060 & .100 & 1 & \\
\hline LOGTA & $-.241 * *$ & -.151 & -.150 & $.484 * *$ & -.092 & -.035 & $.276^{* *}$ & -.159 & $-.184 *$ & .164 & .045 & $.757 * *$ & 1 \\
\hline \multicolumn{4}{|l|}{ Tolerance } & 0.514 & 0.877 & 0.868 & 0.521 & 0.74 & 0.659 & 0.81 & 0.896 & 0.348 & 0.361 \\
\hline \multicolumn{4}{|l|}{ VIF } & 1.945 & 1.141 & 1.152 & 1.919 & 1.351 & 1.518 & 1.23 & 1.116 & 2.873 & 2.77 \\
\hline
\end{tabular}

It means that when the number of independent directors reduces, hotels' performance decreases. On the contrary, BDD, ACC, ACD and age of hotels have a positive relationship with all measures of the financial performance. These findings consistent with (Rizzotti \& Greco, 2013; Vafeas, 1999) affirming the exciting of a positive correlation between BDD and firms' performance. (Arora, 2012) found a positive association between board directors' diligence and firms' performance measured by return on assets and Tobin Q. The result also indicates that elder companies perform better than the younger ones. Marketingbased measure Tobin Q correlates negatively with most of the corporate governance variables in the sector, except audit committee size. Results of multicollinearity tests show that there is no high collinearity among the variables, which indicate the absence of multicollinearity. Looking at the values of tolerance, we do not see any value less than 20 which suggests that there is no multicollinearity. According to statisticians, if VIF for any variable is more than 10 , we definitely have multicollinearity which is not the case in this study, all VIF values are less than 3 .

\subsection{Multiple regression models}

A regression model is a useful tool that tells us whether the independent variable has a significant impact on the dependent variable or not, it is used in this study for investigating the impact of corporate governance parameters on hotels' financial performance. Before applying the regression model and running the analysis, the study tested all assumptions of multiple regression model which were met in this study.

Scatter plot technique was used for examining linearity and homogeneity while Tolerance and VIF tests were used for detecting multicollinearity as shown in the Table 3. Moreover, the normality of residuals was visualized, histogram of residuals shows that residuals seem to have a normal distribution. Regarding autocorrelation, it was noticed that the error terms were not correlated with each other. Finally, Table 5 shows that all models were not suffering from heteroscedasticity. After testing all assumptions of regression model, it was found that Ordinary Least Square regression model is appropriate for estimating the results. 
Regression Models Results

\begin{tabular}{|c|c|c|c|c|c|c|c|c|c|c|c|c|c|c|}
\hline \multicolumn{15}{|c|}{ ROA is the dependent variable } \\
\hline Models & \multicolumn{2}{|c|}{ Model 1} & \multicolumn{2}{|c|}{ Model 2} & \multicolumn{2}{|c|}{ Model3 } & \multicolumn{2}{|c|}{ Model 4} & \multicolumn{2}{|c|}{ Model 5} & \multicolumn{2}{|c|}{ Model 6} & \multicolumn{2}{|c|}{ Model7 } \\
\hline & $\mathrm{B}$ & Prob. & $\mathrm{B}$ & Prob. & $\mathrm{B}$ & Prob. & $\mathrm{B}$ & Prob & B & Prob. & $\mathrm{B}$ & Prob. & $\mathrm{B}$ & Prob. \\
\hline $\mathrm{c}$ & .752 & .025 & .298 & .417 & .353 & .324 & .731 & .028 & .438 & .222 & .041 & .929 & .741 & .033 \\
\hline BDS & -.01 & .269 & & & & & & & & & & & & \\
\hline BDC & & & .598 & .015 & & & & & & & & & & \\
\hline BDD & & & & & .497 & .017 & & & & & & & & \\
\hline ACS & & & & & & & -.03 & .176 & & & & & & \\
\hline ACC & & & & & & & & & .264 & .042 & & & & \\
\hline ACD & & & & & & & & & & & .387 & .034 & & \\
\hline $\mathrm{FO}$ & & & & & & & & & & & & & .001 & .746 \\
\hline Age & .004 & .094 & .006 & .021 & .005 & .067 & .005 & .069 & .006 & .022 & .006 & .018 & .005 & .073 \\
\hline NS & .225 & .117 & .206 & .126 & .211 & .118 & .249 & .088 & .208 & .128 & .329 & .031 & .205 & .169 \\
\hline LOGTA & -.02 & .607 & -.01 & .815 & -.04 & .275 & -.01 & .819 & -.016 & .705 & .007 & .872 & -.04 & .349 \\
\hline $\mathrm{R} 2$ & \multicolumn{2}{|l|}{.160} & \multicolumn{2}{|l|}{.225} & \multicolumn{2}{|l|}{.223} & \multicolumn{2}{|l|}{.169} & \multicolumn{2}{|l|}{.202} & \multicolumn{2}{|l|}{.206} & \multicolumn{2}{|l|}{.144} \\
\hline AdR2 & .102 & & .172 & & .170 & & .112 & & .147 & & .152 & & .085 & \\
\hline F-stat & 2.763 & & 4.219 & & 4.172 & & 2.947 & & 3.662 & & 3.773 & & 2.431 & \\
\hline Prob. & .036 & & .005 & & .005 & & .028 & & .010 & & .009 & & .058 & \\
\hline & & & & & & $\mathrm{CE}$ is $\mathrm{tl}$ & depend & varial & & & & & & \\
\hline Model & Mo & el 1 & $\mathrm{Mc}$ & $\mathrm{el} 2$ & & & & & $\mathrm{Mo}$ & & $\mathrm{Mo}$ & & $\mathrm{Mo}$ & \\
\hline & $\mathrm{B}$ & Prob. & $\mathrm{B}$ & Prob. & B & Prob. & $\mathrm{B}$ & Prob.. & $\mathrm{B}$ & Prob. & $\mathrm{B}$ & Prob. & $\mathrm{B}$ & Prob. \\
\hline c & .691 & .061 & .771 & .004 & .845 & .001 & 13.7 & .001 & .922 & .000 & .978 & .001 & 1.22 & .000 \\
\hline BDS & -.01 & .240 & & & & & & & & & & & & \\
\hline $\mathrm{BDC}$ & & & .647 & .024 & & & & & & & & & & \\
\hline BDD & & & & & .525 & .027 & & & & & & & & \\
\hline ACS & & & & & & & -.42 & .459 & & & & & & \\
\hline ACC & & & & & & & & & .277 & .061 & & & & \\
\hline ACD & & & & & & & & & & & .220 & .245 & & \\
\hline FO & & & & & & & & & & & & & .000 & .772 \\
\hline Age & .005 & .106 & .005 & .092 & .004 & .236 & .004 & .354 & .005 & .121 & .004 & .203 & .004 & .252 \\
\hline NS & -.02 & .602 & .000 & .927 & .000 & .944 & .001 & .004 & -.000 & .795 & -.000 & .733 & -.00 & .742 \\
\hline LOGTA & .291 & .069 & -.06 & .239 & -.09 & .075 & -3.6 & .002 & -.057 & .285 & -.062 & .255 & -.07 & .171 \\
\hline $\mathrm{R} 2$ & .178 & & & & .193 & & .105 & & .174 & & .142 & & .123 & \\
\hline AdR2 & .121 & & .141 & & .138 & & .073 & & .117 & & .083 & & .063 & \\
\hline F-stat & 3.13 & & 3.55 & & 3.47 & & 3.27 & & 3.051 & & 2.406 & & 2.038 & \\
\hline Prob. & .021 & & .012 & & .013 & & .014 & & .024 & & .060 & & .101 & \\
\hline & & & & & & $\mathrm{Q}$ is & depen & t varia & & & & & & \\
\hline Model & Mo & el 1 & $\mathrm{Mc}$ & el 2 & & & & & Mo & & $\mathrm{Mo}$ & & Moc & \\
\hline & B & Prob & B & Prob. & B & Prob. & $\mathrm{B}$ & Prob. & $\mathrm{B}$ & Prob. & B & Prob. & B & Prob. \\
\hline $\mathrm{c}$ & 1.81 & .000 & 2.67 & .000 & 2.07 & .000 & 1.76 & .000 & 2.136 & .000 & 2.634 & .000 & 1.96 & .000 \\
\hline BDS & .02 & .45 & & & & & & & & & & & & \\
\hline $\mathrm{BDC}$ & & & -1.3 & .031 & & & & & & & & & & \\
\hline BDD & & & & & -.19 & .688 & & & & & & & & \\
\hline ACS & & & & & & & .057 & .384 & & & & & & \\
\hline ACC & & & & & & & & & -.234 & .471 & & & & \\
\hline ACD & & & & & & & & & & & -.662 & .109 & & \\
\hline FO & & & & & & & & & & & & & .003 & .376 \\
\hline Age & .012 & .016 & .012 & .016 & .012 & .019 & .011 & .024 & .011 & .022 & .011 & .027 & .013 & .012 \\
\hline NS & .00 & .001 & .00 & .001 & .000 & .000 & .000 & .000 & .000 & .000 & .000 & .000 & .000 & .000 \\
\hline LOGTA & -.54 & .000 & -.54 & .000 & -.52 & .000 & -.54 & .000 & -.539 & .000 & -.573 & .000 & -.56 & .000 \\
\hline $\mathrm{R} 2$ & & & & & .184 & & .189 & & .187 & & .202 & & .189 & \\
\hline AdR2 & & & .188 & & .155 & & .160 & & .158 & & .173 & & .160 & \\
\hline F-stat & & & 7.73 & & & & 6.50 & & 6.434 & & 7.074 & & 6.516 & \\
\hline Prob. & & & .000 & & & & .000 & & .000 & & & & .0 & \\
\hline
\end{tabular}

Table 4 illustrates the results of the ordinary Least Square Regression model that estimates the impact of corporate governance on the financial performance of Indian hotels. The study employed a panel data approach of 39 hotels for the period from 2013/2014 to 2015/2016; 117 firm-year observations. Board directors' size, board directors' composition, board directors' diligence, audit committee's size, audit committee's composition, audit committee's diligence and foreign ownership are proxies for corporate governance while return on assets, return on capital employed and Tobin Q are the proxies for hotels performance. Net sale, age and size of hotels are used as control variables. 


\subsubsection{Accounting based measures}

Return on assets:

Model 1 reports a negative and insignificant impact of board directors' size on hotels performance. This means that when board directors' size enlarges return on assets decreases; it could be explained by the increase in the cost of hiring board members. This result is consistent with (Singh and Davidson, 2003; Cheng, 2008; Adusei, 2012) who argue that board directors' size has a negative association with corporate performance. In the Indian context, Arora, (2012) found that board directors' size negatively impacts return on assets of Indian pharmaceutical companies; These results contradict with the expected results of the study; Similarly, the study findings contradicte with (Adams and Mehran, 2003; Belkhir, 2009; Hussainey and Wang, 2010) who believe that board directors' size positively affects firms' financial performance. In models 2, 3 and 5, it is noticed that board directors' composition, board directors' diligence have a significant positive impact on return on assets, it might be due to the reason that, the executive directors are not in a better condition to keep checking hotels' affairs. Interestingly, Arora (2012) argues that the financial performance of Indian pharmaceutical sector was affected negatively by board directors' composition and positively by board directors' diligence. Model 2 and 3met the expected result which indicates that when board directors' composition and diligence increase by one unit, return on assets of hotels would increase by 59 and 49 percent respectively. On the other hand, it was expected that board directors' diligence negatively impacts hotels' performance, this expectation was contradicted by the result found by the study. Model 5 indicates that an increase in the audit committee composition by one unit leads to an increase in return on assets of hotels by 26 percent; which is in contrast with the predicted result of the study. In model 7 it is clear that foreign ownership positively and insignificantly impacts hotels' performance. It means that when the proportion of foreign ownership in hotels increases return on assets increases as well. This result is consistent with Griffith, (1999) who argue that foreign ownership does not significantly affect firms' performance. The result of model 7 contradicts with Mashayekhi and Bazaz (2008) who found a negative association between foreign ownership and firms' performance. It is also observed that in all models the only control variable that has a significant positive impact on return on assets is the age of hotels, while other variables are insignificant. It is evident that corporate governance focuses on accountability and transparency which are one of the important factors for investors, suppliers, buyers and shareholders, these factors prompt firms' performance and the economy as well. However, there must be a set of democratic market institutions for corporate governance to have an impact on the emerging economy (Feleagă, Feleagă, Dragomir, \& Bigioi, 2011).

\section{Return on capital employed}

As return on assets and return on capital employed are both accounting based measures, most of the results obtained from the regression models are the same except some differences in the quantum of the effect. All models are significantly predicting the outcomes at 5\% level of significant except model 6 and 7 . Model 1 is reporting the same result that was found with the first performance measure (return on assets); the negative impact of board directors' size could be attributed to the disagreement between board members which always does pave the way for better decisions. Results of model 2 and 3 reveal that the board directors' composition and board directors' diligence have a positive impact on return on capital employed of hotels. These mean that the increase in the number of independent board directors and board meetings lead to an increase in the return on capital employed of hotels, this result is consistent with Switzer \& Tang (2009) who found a positive association between the degree of board independence and firms' performance. This result disagrees with Hassan \& Hijazi (2016) who found a negative impact on board meetings on the firm's performance measured by accounting-based- measures. The result of this study is consistent with the agency theory which suggests that when the board of directors meets frequently, they would be able to monitor the 
management which in turn will post the financial performance(Karamanou \& Vafeas, 2005; Mangena \& Tauringana, 2008). One unit change in the board director's composition and board directors' diligence lead to 64 and 52 percent change in return on capital employed respectively. That means when board of directors frequently meet, they devote more time to monitoring the management. This consistent with a study that found that when the boards meet more frequently, the performance increases as a result (Rizzotti \& Greco, 2013; Vafeas, 1999). Model 4 shows that audit committee' size correlates negatively with hotels' performance, which goes in line with Aldamen et al. (2012), who found a negative association between committee size and firms' accounting-based measures. Aldamen et al. (2012) also found a negative association between audit committee's meetings, independence and firms' performance which contradicts with the findings of this study. Model 7 demonstrate insignificant impact for foreign ownership over performance which is the same result that was suggested by (Gedajlovic, Yoshikawa, \& Hashimoto, 2005). This result agrees with the theoretical argument: the ownership structure is supposed to affect the process of decision making which in turn impacts the financial performance of firms. Previous literature demonstrate a positive impact of corporate governance on firms' performance which in turn affect the growth of the economy (Škare \& Hasic, 2009).

\subsubsection{Marketing based measure}

Tobin Q is the marketing based measure that has been taken in this study for reporting the impact of corporate governance practices on the financial performance of Indian hotels. Results in Table 4 show that all models are significantly predicting the outcomes; similarly, controlling variables in all models significantly impact marketing based measure Tobin Q. Results suggest that more than 15\% change in Tobin Q would be attributable to the variables included in the models. In majority of models, we see that corporate governance practices insignificantly impact marketing based measure Tobin $\mathrm{Q}$ at 0.05 level of significance. These results agree with Hassan et al, (2016) who found that most of corporate governance variables insignificantly affect hotels' performance measured by market-based proxies. Model 1 reveals that board directors' size positively and insignificantly affects hotels' performance, this result is in contrast with (Arora, 2012; Citation \& Chatterjee, 2011) who found a negative and significant impact of board directors' size on Tobin Q of Indian pharmaceutical firms. This means that large board directors' size enhances Tobin Q of tourism firms. In model 2 , it is observed that board director's composition significantly and negatively impacts the financial performance of Indian hotels; this result means when board directors' composition increases by 1.3, Tobin Q of Indian hotels decreases by one unit. This result is in the same line with (Singh and Davidson, 2003; Cheng, 2008; Adusei, 2012: Hassan, et al., 2016) who found that board directors' composition negatively impacts firms' performance. (Citation \& Chatterjee, 2011) also found a negative association between board independence and Indian firms performance. It means that when board directors' composition of Indian hotels increases by one unite Tobin Q gets decreases by one unit. This result can be explained by the fact that, internal directors are able to monitor the hotels' affairs better than the outside directors. Aldamen et al. (2012) argue that audit committee characteristics make a difference in firms' performance at the time of financial disruption. Board directors' diligence shows insignificant negative impact on market based measure Tobin Q which contradicts with the results found by (Arora, 2012) who found a positive and significant impact for board directors' diligence on Tobin Q. This indicates that more meetings lead to better financial performance measured by TobinQ. Corporate governance institutions usually try to enhance firms' performance which lead to improving the economy of the country (Eklund, 2014). 


\subsection{Diagnostic test}

Some corrective measures are taken to achieve the validity of the results through the analysis of data. For example, there were some missing values, almost 17 observations were missing from the total number of observations (1153), they were tackled by the mean of the nearby points. Winsorizing technique is used to deal with the outliers, this method was followed by (Martinoz, Haziza, \& Beaumont, 2015). The accounting variables namely ROA and ROCE were lagged to overcome the problem of heteroscedasticity and autocorrelation.

Table 5

Heteroscedasticity Test Results

\begin{tabular}{|c|c|c|c|c|c|c|c|c|c|c|c|c|c|c|}
\hline \multicolumn{15}{|c|}{ Koenker test statistics and sig-values } \\
\hline & \multicolumn{2}{|c|}{ Model 1} & \multicolumn{2}{|c|}{ Model 2} & \multicolumn{2}{|c|}{ Model 3} & \multicolumn{2}{|c|}{ Model 4} & \multicolumn{2}{|c|}{ Model 5} & \multicolumn{2}{|c|}{ Model 6} & \multicolumn{2}{|c|}{ Model 7} \\
\hline & LM & Sig & LM & Sig & LM & Sig & LM & Sig & LM & Sig & LM & Sig & LM & Sig \\
\hline $\mathrm{ROA}$ & .408 & .843 & 5.997 & .199 & 2.2 & .68 & 2.104 & .717 & .795 & .939 & 2.40 & .662 & 1.78 & .775 \\
\hline ROCE & 1.81 & .770 & 7.770 & .100 & 3.7 & .443 & 2.274 & .686 & 1.342 & .854 & 2.9 & .565 & 2.78 & .594 \\
\hline Tobin Q & 4.90 & .297 & 6.898 & .141 & 4.9 & .29 & 4.910 & .297 & 5.135 & .274 & 6.19 & .185 & 5.00 & .287 \\
\hline
\end{tabular}

For dealing with heteroscedasticity, Koenker test was used; the null hypothesis states that there is no heteroscedasticity in the model. Table 5 shows that all null hypotheses have been accepted in all models which means there is no heteroscedasticity in the four models.

\section{CONCLUSION}

The study aimed to evaluate corporate governance effect on the performance of Indian hotels. A panel data set of 39 hotels listed on the Bombay Stock Exchange for three years was used. Empirical evidence was drawn with the help of the SPSS and Eveiws software programs. The study used accounting and marketing-based measures for measuring the financial performance of Indian hotels. The study employed a panel data approach of 39 hotels for the period from 2013/2014 to 2015/2016; 117 firm-year observations. Board directors' size, board directors' composition, board directors' diligence, audit committee's size, audit committee's composition, audit committee's diligence, and foreign ownership are proxies for corporate governance while return on assets, return on capital employed, and Tobin Q are the proxies for hotels' performance. Net sale, age, and size of hotels are used as control variables.

The study found in cross-sectional descriptive statistics that there is a slight improvement in corporate governance practices in terms of board directors over the study period. Moreover, there is a fluctuation in corporate governance practices regarding audit committee over the study period. It is also observed that the financial performance of the selected hotels during the years of study is fluctuating, only one variable of financial performance showed a continuous increase which is earnings per share. Furthermore, it is imperially found that corporate governance has mixed of positive and negative association with accountingbased measures of financial performance in Indian hotels. Regarding foreign ownership, it is observed that there is a continuous decline over the study period. The study found that board directors' size does not have a significant impact on the financial performance of Indian hotels, whereas the composition of the board and their diligence have a significant impact on the financial performance of Indian hotels. In brief, corporate governance practices in the hotel industry need a huge effort to be improved in order to be considered as a good practitioner of corporate governance. 


\section{LIMITATIONS AND FUTURE DIRECTIONS}

The study is limited to hotels that are listed on Bombay Stock Exchange, due to non-availability of data of non-listed hotels. As corporate governance has a large number of parameters, this study selected the most relevant variables; further studies shall take the other remaining variables of corporate governance. The study is based on three years of data; therefore, future studies can be conducted taking more than five years which may give more reliable results. Moreover, it is advised for further studies to be conducted by using primary data.

\section{REFERENCES}

Achchuthan, S., \& Kajananthan, R. (2013). Corporate governance practices and working capital management efficiency: special reference to listed manufacturing companies in Sri Lanka. Information and Knowledge Management, 3(2), 216-226. Retrieved from http:/ / search.ebscohost.com/login.aspx?direct $=$ true\&profile $=$ ehost\&scope $=$ site\&authtype $=$ crawler\&jrnl $=22$ 24896X\&AN=89001541\&h=a0sz9CdC4XqZ9yIDpPB2Tx2g9MNLI3iGFr01w324fUSmUMTnsCUuQpadfpa $\mathrm{sd} 96 \mathrm{phCUhIgFUz} / \mathrm{K}+\mathrm{Ix}+\mathrm{n} 5 \mathrm{z} 64 \mathrm{yw}==\& \mathrm{crl}=\mathrm{c}$

Afrifa, G. A. (2016). Net working capital, cash flow and performance of UK SMEs. Review of Accounting and Finance, 15(1). https://doi.org/10.1108/RAF-02-2015-0031

Afrifa, G. A., \& Padachi, K. (2016). Working capital level influence on SME profitability. Journal of Small Business and Enterprise Development, 23(1), 44-63.

Agrawal, A., \& Knoeber, C. . (1996). Firm performance and mechanisms to control agency problems between managers and shareholders. J. Financ. Quant. Anal, (31), 377-397.

Agyei, A., \& Owusu, A. R. (2014). The effect of ownership structure and corporate governance on capital structure of Ghanaian listed manufacturing companies. International Journal of Academic Research in Accounting, Finance and Management Sciences, 4(1), 109-118. https://doi.org/10.6007/IJARAFMS/v4-i1/547

Akbar, S., Poletti-hughes, J., El-faitouri, R., \& Zulfiqar, S. (2016). Research in international business and finance more on the relationship between corporate governance and firm performance in the UK: Evidence from the application of generalized method of moments estimation. Research in International Business and Finance, 38, 417429. https://doi.org/10.1016/j.ribaf.2016.03.009

Al-bassam, W. M., Ntim, C. G., Opong, K. K., \& Downs, Y. (2015). Corporate boards and ownership structure as antecedents of corporate governance disclosure in Saudi Arabian publicly listed corporations. Business \& Society, sagepub.co, 1-43. https://doi.org/10.1177/0007650315610611

Al-Janadi, Y., Rahman, R. A., \& Alazzani, A. (2016). Article information : Does government ownership affect corporate governance and corporate disclosure? Evidence from Saudi Arabia. Managerial Auditing Journal, 3(8/9), 1-24.

Al-Rahahleh, A. S. (2016). Corporate governance quality and earnings management: Evidence from Jordan. Australasian Accounting, Business and Finance Journal, 10(2), 54-75. https://doi.org/10.14453/aabfj.v10i2.4

Alabdullah, T. T. Y., Yahya, S., Nor, M. I., \& Majeed, F. Q. (2016). An investigation of corporate governance from a new perspective: Examining the financial performance of companies and the impact of executive turnover. Corporate Board: Role, Duties and Composition, 12(1), 53-69.

Aldamen, H., Duncan, K., Kelly, S., McNamara, R., \& Nagel, S. (2012). Audit committee characteristics and firm performance during the global financial crisis. Account. Finance, (52), 971-1000.

Aljaaidi, K. S. Y. (2013). Corporate governance and auditor choice among companies in gcc countries, Thesis Submitted to Othman Yeop Abdullah Graduate School of Business Universiti Utara Malaysia in Fulfillment of the Requirement for the Degree of Doctorof Philosophy.

Anderson, R. C., Mansi, S. A., \& Reeb, D. M. (2004). Board characteristics, accounting report integrity, and the cost of debt. Journal of Accounting and Economics, 37(3), 315-342. https://doi.org/10.1016/j.jacceco.2004.01.004

Arora, A. (2012). Corporate governance and firm performance in Indian pharmaceutical sector. An International Journal, $40(6), 537-550$.

Arora, A., \& Sharma, C. (2015). Impact of firm performance on board characteristics: Empirical evidence from India. IIM Kozbikode Society \& Management Review, 4(1), 53-70. https://doi.org/10.1177/2277975215595559

Arora, A., \& Sharma, C. (2016). Corporate governance and firm performance in developing countries: evidence from 
India. Corporate Governance (Bingley), 16(2), 420-436. https://doi.org/10.1108/CG-01-2016-0018

Arouri, H., \& Hossain, M. (2014). Effects of board and ownership structure on corporate performance Evidence from GCC countries. Journal of Accounting in Emerging Economies, 4(1), 117-130. https://doi.org/10.1108/JAEE-022012-0007

Bassen, A. (2004). The implementation of good corporate governance by institutional investors. International Journal of Disclosure and Governance, 2(3), 244-263.

Bayrakdaroglu, A., Ersoy, E., \& Citak, L. (2012). Is there a relationship between corporate governance and value-based financial performance measures? A study of Turkey as an emerging market. Asia-Pacific Journal of Financial Studies, 41(2), 224-239. https://doi.org/10.1111/j.2041-6156.2012.01071.x

Bédard, J., Chtourou, S. M., \& Courteau, L. (2004). The effect of audit committee expertise independence, and activity on aggressive earnings management. A Journal of Practice \& Theory, (23), 13-35.

Bhagat, S., \& Blak, B. (2016). The uncertain relationship between board composition and firm performance. American Bar Association, 54(3), 921-963.

Bhagat, S., \& Bolton, B. (2008). Corporate governance and fi rm performance. Journal of Corporate Finance Journal, 14, 257-273. https://doi.org/10.1016/j.jcorp

Bhagat, S., \& Bolton, B. (2008). Corporate governance and firm performance. J. Corp. Finance, (14), 257-273.

Brahmapurkar, A., Sahay, M., \& Gupta, K. K. (2015). Tourism industry in India and Asean countries - a comparative study.

Chan, K. C., \& Li, J. (2008). Audit committee and firm value: evidence on outside top executives as expert-independent directors, corporate governance. International Review.

Chauhan, Y., Lakshmi, K. R., \& Dey, D. K. (2016). Corporate governance practices, self-dealings, and firm performance: Evidence from India. Journal of Contemporary Accounting \& Economics, 12(3), 274-289. https://doi.org/10.1016/j.jcae.2016.10.002

Chitiavi, M. S., Musiega, M. G., Alala, O. B., Douglas, M., \& Christopher, M. O. (2013). Capital structure and performance: evidence from listed non-financial firms on Nairobi Securities Exchange (Nse) Kenya. International Journal for Management Science and Technology (IJMST), 1(2), 1-16.

Citation, S., \& Chatterjee, S. D. (2011). Board composition and performance in Indian firms: A comparative analysis empirical. He International Journal of Management Science and Information Technology (IJMSIT).

Detthamrong, U., Chancharat, N., \& Vithessonthi, C. (2017). Corporate governance, capital structure and firm performance: Evidence from Thailand. Research in International Business and Finance, 42(July), 689-709. https://doi.org/10.1016/j.ribaf.2017.07.011

Duffhues, P., \& Kabir, R. (2008). Is the pay-performance relationship always positive? Evidence from the Netherlands. J. Multinatl. Financ. Manage, (18), 45-60.

Eklund, J. E. (2014). Corporate governance, entrepreneurship and economic development.

Elangkumaran, P., \& Karthika, T. (2013). An analysis of liquidity, profitability and risk: - A study of selected listed food, beverage and tobacco companies in Sri Lanka. 3rd International Conference, South Eastern University of Sri Lanka, (1), 1-7.

Fallatah, Y., \& Dickins, D. (2012). Corporate governance andfirm performance and value in Saudi Arabia. African Journal of Business Management, 6(36), 10025-10034 DOI: 10.5897/AJBM12.008. https://doi.org/10.5897/AJBM12.008

Fama, E. (1980). Agency problem and the theory of the business. Journal of Political Economy, (88), 134-145.

Fama, E., \& Jensen, M. (1983). Separation of ownership and control. Journal of Law and Economics, (26), 301-325.

Feleagă, N., Feleagă, L., Dragomir, V. D., \& Bigioi, A. D. (2011). Corporate governance in developing and emerging countries. The case of Romania. Theoretical and Applied Economics, 9(562), 5-16.

Fiador, V. (2016). Does corporate governance influence the efficiency of working capital management of listed firms - evidence from Ghana. African Journal of Economic and Management Studies, 7(4), 482-496.

Filatotchev, I., Isachenkova, N., \& Mickiewicz, T. (2007). Corporate governance, managers' independence, exporting and performance of firms in transition economies. Emerging Markets Finance and Trade, 43(5), 62-77.

Francis, B., Hasan, I., \& Wu, Q. (2012). Professors in the boardroom and their impact on corporate governance and firm performance. SSRN Working Paper.

Gani, L., \& Jermias, J. (2006). Investigating the effect of board independence on performance across different strategies. The International Journal of Accounting, (41), 295-3 14.

Gedajlovic, E., Yoshikawa, T., \& Hashimoto, M. (2005). Ownership structure, investment behaviour and firm 
performance in Japanese manufacturing industries. Organization Studies, 26(1), 7-35.

Ghabayen, M. A. (2012). Board characteristics and firm performance : Case of Saudi Arabia. International Journal of Accounting and Financial Reporting, 2(2), 168-200. https://doi.org/10.5296/ijafr.v2i2.2145

Gill, A., Biger, N., \& Obradovich, J. (2014). The impact of independent directors on the cash conversion cycle of American manufacturing firms. International Journal of Economics and Finance, 7(1), 87-96. https://doi.org/10.5539/ijef.v7n1p878

Gull, A. A., Saeed, A., \& Abid, A. (2013). Corporate governance and performance: An empirical evidence from textile sector of Pakistan. African Journal of Business Management, 7(22), 2112-2118. https://doi.org/10.5897/AJBM2013.6952

Hassan, Y. M., Box, P. O., Ain, A., \& Hijazi, R. H. (2016). The influence of corporate governance on corporate performance : evidence from Palestine Kamal Naser. Afro-Asian J. Finance and Accounting, 6(3), 269-287.

Hutchinson, M., \& Gul, F. A. (2004). Investment opportunity set, corporate governance practices and firm Performance. Journal of Corporate Finance, (10), 595-614.

Ibrahim, H., \& AbdulSamad, F. A. (2011). Corporate governance mechanisms and performance of public-listed familyownership in Malaysia. International Journal of Economics and Finance, 3(1), 105-115.

Ibrahim, K., \& Jaafar, H. (2013). Corporate governance and disclosure on segment reporting : Evidence from Nigeria. In Global Business and Finance Research Conference (pp. 1-19).

Jackling, B., \& Johl, S. (2009). Board structure and firm performance: evidence from India's top companies. Corp. Gov.: An Int. Rev, (17), 492-509.

Jo, H., \& Harjoto, M. A. (2011). Corporate governance and firm value : The impact of corporate social responsibility. Journal of Business Ethics, (103), 351-383. https://doi.org/10.1007/s10551-011-0869-y

Johl, S. K., Kaur, S., \& Cooper, B. J. (2015). Board characteristics and firm performance: evidence from Malaysian public listed firms. Journal of Economics, Business and Management, 3(2), 239-243. https://doi.org/10.7763/JOEBM.2015.V3.187

JonesLangLaSalleHotels. (2008). Asia overview digest 2008. Available at: Www. Joneslanglasallehotels.Com/EnUS/Research/Researchabstract? Artid $1 / 43435$.

Kang, S., \& Kim, Y. (2011). Does earnings management amplify the association between corporate governance and firm performance ?: Evidence from Korea. International Business \& Economies Research Journal, 10(2), $53-67$.

Karaca, S. S., \& Ekşi, İ. H. (2012). The relationship between ownership structure and firm performance: An empirical analysis over İstanbul Stock Exchange(ISE) Listed Companies. International Business Research, 5(1), 172-181.

Karamanou, I., \& Vafeas, N. (2005). The association between corporate boards, audit committees, and management earnings forecasts: an empirical analysis. Journal of Accounting Research, 43(3), 453-486.

Khanna, V., \& Black, B. (2007). Can corporate governance reforms increase firm's market values? Evidence from India. Journal of Empirical Legal Studies, 4, 749-796.

Mahadeo, J. D., Soobaroyen, T., \& Hanuman, V. O. (2012). Board composition and financial performance: Uncovering the effects of diversity in an emerging economy. Journal of Business Ethics, 105(3), 375-388. https://doi.org/10.1007/s10551-011-0973-z

Malik, M. M., \& Nusrath, A. (2014). A review of tourism development in India. Golden Research Thoughts, 3(11).

Mangena, M., \& Tauringana, V. (2008). Audit committees and voluntary external auditor involvement in UK interim reporting. International Journal of Auditing, 12(1), 45-63.

Martinoz, C. F., Haziza, D., \& Beaumont, J. F. (2015). A method of determining the winsorization threshold, with an application to domain estimation. Survey Methodology, 41(1), 57-77.

Mashayekhi, B., \& Mohammad, S. B. (2008). Corporate governance and firm performance in Iran. Journal of Contemporary Accounting \& Economics, 4(2), 156-172. https://doi.org/10.1016/S1815-5669(10)70033-3

Mehta, M. S. P. (2017). Working capital management and firms ' profitability: Evidence from emerging Asian countries. South Asian Journal of Business Studies, $6(1 \mathrm{pp})$.

Mohamed, S., Ahmad, K., \& Khai, K. (2016). Corporate governance practices and firm performance : Evidence from top 100 public listed companies in malaysia. Procedia Economics and Finance, 35(October 2015), $287-296$. https://doi.org/10.1016/S2212-5671(16)00036-8

Mousa, G. A., \& Desoky, A. M. (2012). The association between internal governance mechanisms and corporate value: Evidence from bahrain. Asian Academy of Management Journal of Accounting and Finance, 8(SUPPL.), 67-91.

Nahar Abdullah, S. (2004). Board composition, CEO duality and performance among Malaysian listed companies. 
Corporate Governance: The International Journal of Business in Society, 4(4), 47-61. https://doi.org/10.1108/14720700410558871

National Foundation For Corporate Governance. (2004). Corporate governance in listed companies - clause 49 of the listing agreement. Available at: Www.Nfcgindia.Org/ Clause2004.Htm.

Nilsson, G. O. (2007). Corporate governance in Turkey. European Business Organization Law Review (EBOR), 8(02), 195. https://doi.org/10.1017/S1566752907001954

Pillai, R., \& Al-Malkawi, H.-A. N. (2017). On the relationship between corporate governance and firm performance: Evidence from GCC countries. Research in International Business and Finance, (July), 0-1. https://doi.org/10.1016/j.ribaf.2017.07.110

Planning Commissio Government of India. (2007). Towards faster and more inclusive growth - an approach to the 11th five year plan 2007-2012.

Priego, A. M., \& Merino, E. (2016). Corporate governance effect on financial distress likelihood : Evidence from Spain. Cómo Citar Este Artículo:, 19(1), 111-121. https://doi.org/10.1016/j.rcsar.2015.04.001

Rabelo, F. M., \& Vasconcelos, F. C. (2002). Corporate governance in Brazil. Journal of Business Ethics 37:, 37, $321-335$.

Rajab, B., \& Handley-Schachler, M. (2009). Corporate risk disclosure by UK firms: trends and determinants. World Review of Entrepreneurship, Management and Sustainable Development, 5, 224-243.

Rhoades, D. L., Rechner, P. L., \& Sundaram, C. (2017). Board composition and financial performance: A Meta- analysis of the influence of outside directors. Journal of Managerial ISSUES, 12(1), 76-91.

Rizzotti, D., \& Greco, A. M. (2013). Determinants of board of statutory auditor and internal control committee diligence: A comparison between audit committee and the corresponding italian committees. International Journal of Accounting, 48(1), 84-110. https://doi.org/10.1016/j.intacc.2013.01.007

Singh Jaswal, S. (2014). Role of tourism industry in India's development. Journal of Tourism \& Hospitality, 04(02), 2-7. https://doi.org/10.4172/2167-0269.1000126

Škare, M., \& Hasic, T. (2009). Experiences of stigma and discrimination among adults living with hiv in a low hivprevalence context: a qualitative analysis. Journal of Business Economics and Management ISSN, 17(1), $267-276$. https://doi.org/10.3846/16111699.2015.1071278

Switzer, L. N., \& Tang, M. (2009). The Impact of corporate governance on the performance of U . S . Small-Cap firms. International Journal of Business Research and Management, 14(4), 341-355.

Tabash, M. I., Yahya, A. T., \& Akhtar, A. (2017, November). Financial Performance Comparison of Islamic and conventional banks in the United Arab Emirates (UAE). In International Conference on Advances in Business, Management and Law (ICABML) 2017 (Vol. 1).

Thiruvadi, S. (2012). Gender differences and audit committee diligence. Gender in Management: An International Journal, 27(6), 366-379. https://doi.org/10.1108/17542411211269310

Uadiale, O. M. (2010). Impact of board structure on corporate financial performance in Nigeria. International Journal of Business and Management, 5(10), 155-166.

Vafeas, N. (1999). Board meeting frequency and firm performance. Journal of Financial Economics, (53), $113-142$.

Wiwattanakantang, Y. (2001). Controlling shareholders and corporate value: evidence from Thailand. J. Corp. FinancePac.-Basin Finance, (9), 323-362.

Yahya, A. T., Akhtar, A., \& Tabash, M. I. (2017). The impact of political instability , macroeconomic and bank-specific factors on the profitability of Islamic banks : an empirical evidence. Investment Management and Financial Innovations, 14(4), 30-39. https://doi.org/10.21511/imfi.14(4).2017.04

Yang, T., \& Zhao, S. (2014). CEO duality and firm performance: evidence from an exogenous shock to the competitive environment. J. Bank. Finance, (4), 534-552.

Yermack. (1996). Higher market valuation of companies with a small board of directors. D., 1996. J. Financ. Econ., (40), 185-211. 